\title{
Effectiveness of the application of Quantum Learning Model in terms of students' written mathematical communication skills
}

\author{
Dimiati Utari, Dwi Priyo Utomo, Zukhrufurrohmah \\ Department of Mathematics Education, Faculty of Teacher Training and Education, \\ University of Muhammadiyah Malang \\ E-mail : dimiatiutari@gmail.com
}

\begin{abstract}
This research aimed (1) describe the implementation of learning in the classroom with the Quantum Learning model, (2) describe the students' written mathematical communication skills with Quantum Learning, and (3) describe the effectiveness of applying the Quantum Learning model to the written mathematics communication skills of junior high school students class VIII. The research was conducted in the even semester of the 2019/2020 school year in class VIII of SMP Muhammadiyah 2 Malang. This research is a type of descriptive research with quantitative methods. The initial stage of the research is the planning stage starting from determining the location and time of the study up to the validation of the research instruments used. The next stage is the implementation stage which is held three times by giving a description test to measure the ability of written mathematical communication at the third or final meeting. The last step is analyzing data obtained from the field. The data analysis technique used descriptive statistics. The results showed the average overall implementation of learning was in the good criteria of $83.92 \%$. The ability of written mathematics communication in grade VIII A students of SMP Muhammadiyah 2 Malang is a very good criterion of 3.04. Therefore, it can be concluded that the application of the Quantum Learning model is effective to the written mathematics communication of junior high school students, especially in class VIII A.
\end{abstract}

Keywords: Effectiveness, Quantum Learning, The implementation of learning, written mathematics communication

\section{INTRODUCTION}

The learning process in the classroom, teachers and students exchange ideas through communication in the form of the process of conveying, listening, writing, understanding, and evaluating. Mathematical communication is one of the important to the success of the five basic abilities of students in learning mathematics (Sari, 2017). Basically, communication aims to convey messages and information that are useful to stimulate students' thoughts, feelings and interest in learning (Haryoko, 2009). Therefore, mathematics communication in learning between teachers and students must run optimally. Mathematical communication skills are very important for students, because they can affect many things, including in everyday life (Yaniawati, 2019). Mathematical communication skills in the learning process are the teacher is able to make learning situations interesting and easy to understand. So that during situations like this students get the opportunity to develop their own independent concept understanding skills, how to solve problems, express their mind through writing or verbally, and accept the thoughts of other students and criticize them (Supandi, Rosvitasari, \& Kusumaningsih, 2017). 
Students' mathematical communication skills in learning can be enhanced by implementing learning models that create an effective learning environment by directly involving students and using the learning environment as a forum for interaction between teachers and students (Danaryanti \& Sari, 2014). The learning model that is expected to be able to develop students' mathematical communication is the Quantum Learning model (Danaryanti \& Sari, 2014). The concept of the Quantum Learning model is to reconstruct themselves and knowledge based on students' experiences with a modified step called "TRIRagaJauH" Improve/Tingkatkan, Feel/Rasakan, Identify/Identifikasikan, Demonstrate/Peragakan, Review/Tinjau kembali, Respect/Hargai (DePorter, Reardon, \& Nourie, 2010). Increase the need to know, identify, provide "learning information", as learning interest increases, demonstrate, give students the opportunity to associate the experience with new learning information, so that it becomes a new learning experience for students, review the learning material, if worth learning, worth celebrating too. Quantum Learning is a learning model that provides opportunities for students to reconstruct their abilities and build knowledge from student experiences with guide questions given by teachers so that students more easily understand the concepts taught and communicate their thoughts through writing and orally (Darkasyi, Johar, \& Ahmad, 2014; Kusno \& Purwanto, 2011). The learning model is applied in class according to its effectiveness.

Effectiveness is an effort to achieve the goals that have been designed and in accordance with the initial objectives (Agustina \& Sanjaya, 2016). A learning process is said to be effective in terms of student activities in the class during the learning process, teacher activities in the learning process, student responses to learning, mastery of concepts, and achievement of learning goals(Lubis, Sari, \& Cipta, 2017; Marwoto Saiman \& Slameto, 2008; Rohmawati, 2015). The effectiveness criteria in this research were seen from the observation sheet of the implementation of learning which obtained a score of $\geq$ 70 which was in good criteria, and the ability to write mathematics communication of students who obtained an average of all indicators $>2$ that were in good criteria.

The results of observations from the third internship at SMP Muhammadiyah 2 Malang, VIII grade students tend to be passive during the learning process. Active involvement of students in learning activities is needed (Wigati, 2016). Students are not good at writing mathematical symbols and notations, students are only able to mention mathematical symbols and notations. Students also choose to be quiet when students do not understand the material. This incident is due to the selection of a learning model that is less precise and monotonous and is only teacher-centered. This makes it a habit that most students only receive learning information from the teacher without wanting to explore and find solutions to the problems of a material independently. Students are not accustomed to expressing their thoughts verbally or in writing and even students have not been able to learn independently (Tasaik \& Tausikal, 2018). Therefore, the right solution is needed to involve students in the learning process in the classroom so that students' mathematical communication can be maximized during the learning process.

Based on research conducted by Elli and Manopo (2016), with Classroom Action Research (CAR) or Penelitian Tindak Kelas (PTK) learning activities carried out with two cycles that use the Quantum Learning model both to improve students' mathematical communication skills and improve student learning activities in class. The difference between this research and Elli and Manopo (2016) is that in this research, it didn't use Classroom Action Research and wasn't cyclic. The instrument used in this research was the observation sheet of the implementation of learning and the test sheet. Indicators of 
success or effectiveness criteria in this research differ from previous studies, as seen from the observation sheet of the implementation of learning that scores $\geq 70$ which are in good criteria, and the ability to write mathematical communication of students who get an average score of each indicator> 2 which is on the criteria good.

Therefore, research will be conducted on (1) how is the implementation of learning in the classroom with the Quantum Learning model ?, (2) what is the ability of students to write mathematics communication with Quantum Learning ?, and (3) how to effectively apply the Quantum Learning model to mathematics communication skills of junior high school students?. The purpose of the research is (1) describe the implementation of learning in the classroom with the Quantum Learning model, (2) describe the students' written mathematical communication skills with Quantum Learning, and (3) describe the effectiveness of applying the Quantum Learning model to the written mathematics communication skills of junior high school students class VIII.

\section{RESEARCH METHODS}

The research was conducted in the even semester of the 2019/2020 school year in class VIII of SMP Muhammadiyah 2 Malang. This research is a type of descriptive research with a quantitative approach. Descriptive type is used by researchers to describe the implementation of learning in the classroom with Quantum Learning models, describe students 'written mathematical communication skills with Quantum Learning, and describe the effectiveness of applying the Quantum Learning model to students' written mathematical communication skills. While the quantitative method is used to collect research data in the form of numerical scores through the observation sheet of the implementation of learning, and tests.

This research procedure consists of three stages. The first stage is, the planning stage, the second stage is the implementation, and the third stage is the analysis. The planning is carried out before the research is carried out starting from the determination of the location and time of the study until the validation of the research instruments to be used. The implementation is carried out in class three times by giving a description test to measure the ability of written mathematical communication at the third or final meeting. The last step is analyzing the results of students' written tests. After analyzing the test results, a conclusion can be drawn for the effectiveness of the Quantum Learning model on students' written communication skills with the criteria provided.

Data collection techniques were carried out to collect relevant data for this research, namely the Quantum Learning model and students' written communication skills. Data analysis techniques and instruments used were tests and observations. The test is given in the form of a written test with a description of the problem. This written test aims to determine the extent of mathematics communication skills of students in class VIII on the circle material after the implementation of Quantum Learning. The Observation was carried out with a learning implementation observation sheet consisting of several indicators that would be analyzed with calculations that had been designed. The Observation sheet is used to determine the feasibility of learning that takes place in class. 


\section{RESULTS AND DISCUSSION}

\section{Implementation of the Quantum Learning Model}

The learning process in class is contained in the Rencana Pelaksanaan Pembelajaran (RPP). The implementation of learning is seen from the learning steps in the lesson plan as a reference in making an observation sheet of the implementation of learning.

The results of the recapitulation of the observations score of learning achievement in class are in Table 1:

Table 1: Recapitulation of the result of the implementation of Quantum Learning

\begin{tabular}{|c|c|c|c|}
\hline No. & Implementation of Learning & Score & Criteria \\
\hline 1 & First Meeting & 77,6 & Good \\
\hline 2 & Second Meeting & 82,73 & Good \\
\hline 3 & Third Meeting & 91,43 & Very Good \\
\hline & Average & 83,92 & Good \\
\hline
\end{tabular}

The first meeting on learning was $77.6 \%$ which was classified as good criteria. This is because there is one learning step that is not implemented, namely the group leader submits the exchange paper mechanism to each group member. This happened, because only a few group leaders understood the purpose of the learning mechanism the teacher explained. Therefore, to re-condition the class, the teacher returns the exchange paper mechanism to all students without going through the group leader. Re-clarification of this mechanism affects the next learning step because of the time allocation used. Quantum Learning method with the step "TRIRagaJauH" provides an opportunity for students to reconstruct learning from experience with the concept of "AGUnK" (Apa Gunanya Untuk $K u$ /What's in it for Me). This is in line with research conducted by Sudarman \& Vahlia (2016) that students are interested in mathematics after linking daily experiences with mathematics subject matter (Sudarman \& Vahlia, 2016). The Demonstration stage is very influential on students in explaining problems in everyday life by finding ways and discussions in their en language. A teacher in a constructive class will not teach students to solve problems in the way provided, but in ways and discussions that they find themselves (Lusiana, Hartono, \& Saleh, 2013; Martunis, Ikhsan, \& Rizal, 2014).

The second meeting in the class was held well which was $82.73 \%$. Seen in the second meeting has a higher score presentation than the first meeting because all the steps of Quantum Learning with the "TRIRagaJauH" step have been implemented. Learning is made interesting and fun with music playing and group discussions. Quantum Learning model as one of the fun learning models in the classroom (Darkasyi et al., 2014; Elli \& Manopo, 2016).

The implementation of the learning of the third meeting or the last meeting carried out a written communication skills test was carried out very well by $91.43 \%$. Based on the average total score of observations of the feasibility of learning to run well by $83.92 \%$. 
Based on the results of observations of the implementation of learning in class VIII A SMP Muhammadiyah 2 Malang in the first to the third meeting using the Quantum Learning model implemented well. This is in line with Rohim's research (2015) The application of the Quantum Learning model is well implemented, shortcomings in each meeting can be corrected by the teacher for the next meeting-

\section{Writing Mathematics Communication Ability}

The students' written mathematics communication skills can be known from the results of the written test held at the third meeting. The results of the test can show the high or low ability of students' written mathematics communication. There are three indicators to measure students' written mathematical communication skills.

The written mathematics communication indicators and the results of the score recapitulation are provided in Table 2:

Table 2: Recapitulation of Written Mathematical Communication Ability Indicators

\begin{tabular}{|c|c|c|c|c|c|c|c|}
\hline \multirow{2}{*}{ No } & Written Mathematical & \multicolumn{6}{|c|}{ Score } \\
\hline & Communication Ability Indicators & $\mathbf{0}$ & 1 & 2 & 3 & 4 & Average \\
\hline 1 & $\begin{array}{l}\text { States everyday events in language or } \\
\text { mathematical symbols }\end{array}$ & & & 3 & 7 & 14 & 3,46 \\
\hline $\begin{array}{l}2 \\
3\end{array}$ & $\begin{array}{l}\text { Write down mathematical concepts and ideas in } \\
\text { the form of images and equations }\end{array}$ & 3 & $\begin{array}{l}5 \\
1\end{array}$ & & $\begin{array}{l}1 \\
4\end{array}$ & $\begin{array}{l}18 \\
16\end{array}$ & 3,27 \\
\hline $\begin{array}{l}4 \\
5\end{array}$ & $\begin{array}{l}\text { Write down mathematical information in the } \\
\text { form of notations and symbols }\end{array}$ & $\begin{array}{l}5 \\
5\end{array}$ & 1 & $\begin{array}{l}2 \\
6\end{array}$ & $\begin{array}{c}13 \\
5\end{array}$ & $\begin{array}{l}4 \\
7\end{array}$ & 2,40 \\
\hline & Total Average & & & & & & 3,04 \\
\hline
\end{tabular}

The first indicator is, stating everyday events in language or mathematical symbols are in very good criteria of 3.46. The second indicator, writing mathematical concepts and ideas in the form of pictures and equations, is very good at 3.27. The third indicator, which is to write mathematical concepts and ideas in the form of pictures and equations, has the lowest average of the two previous indicators, but it still falls to the good criteria of 2.40. Seen from Table 4, the overall indicator average of 3.04, which means students of class VIII A of SMP Muhammadiyah 2 Malang have excellent levels of mathematical communication skills.

Of the three indicators provided, there is one indicator that is below the total average, namely the indicator of writing mathematical information in the form of notations and symbols of 2.40. The indicator to write mathematical information in the form of notations and symbols is implemented in questions number 4 and 5 . 


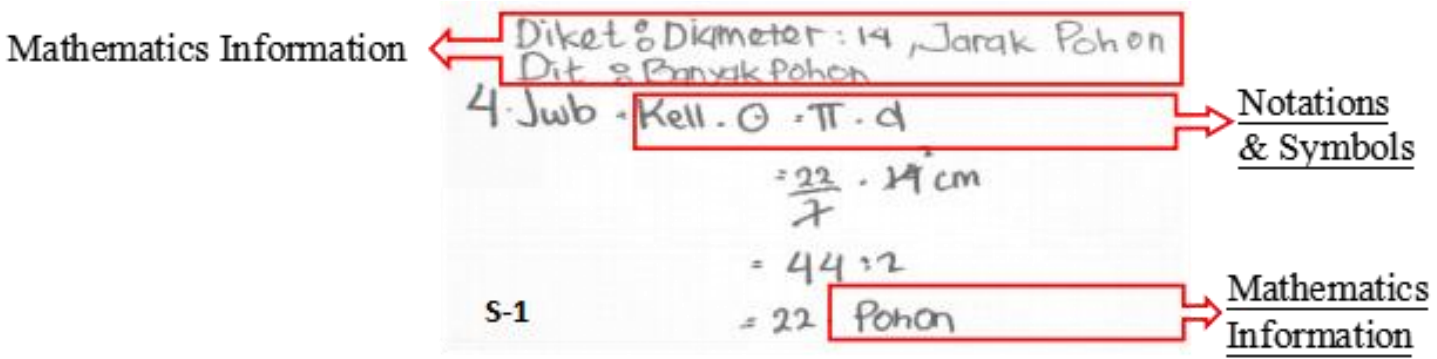

Figure 1. Results of correct student answers number 4

Figure 1 shows the results of student answers that are complete and correct. Student 1 (S1) gets a maximum score of 4 by the scoring guidelines, because writing down complete answers ranging from mathematical information to notation and symbols correctly in accordance with the instructions given.

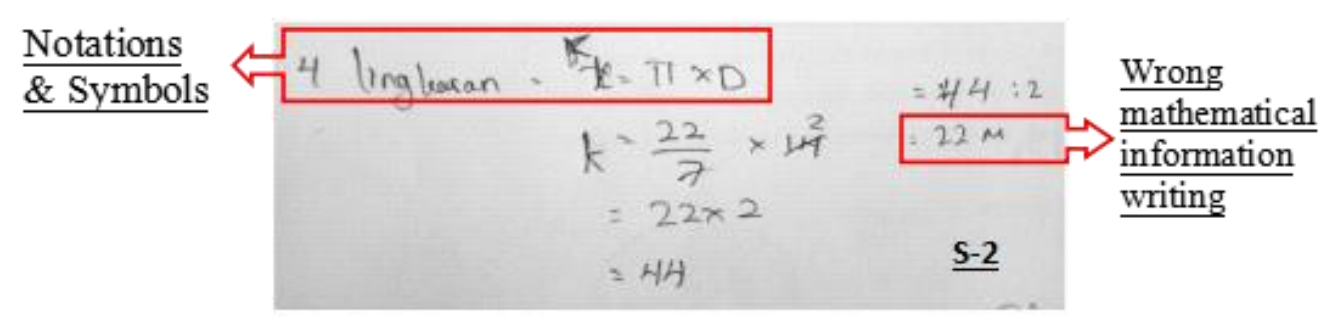

Figure 2. The results of students' answers that aren't right number 4

The difference between Figure 1 and Figure 2 regarding the results of student answers. Figure 2 shows the results of students' answers that are not right, this causes some scores to decrease in the third indicator. Student 2 (S-2) does not write down mathematical information as it is known and asked. This is in line with the research of Ramadhan \& Minarti (2018) that students are lazy in writing what is known and what is asked, whereas in completing a story problem it is necessary to see from the process of working on the questions (Ramadhan \& Minarti, 2018). Student 2 (S-2) also misplaced mathematical information in the final answer, it appears that students did not understand the problem because they wrote the unit of length on the final answer that should have been filled with the number of trees. This is in line with the results of Ningrum's research (2013) that students have a deficiency in reading and understanding story problems and other errors that often occur are the drawing of inaccurate conclusions (Ningrum, 2013). 


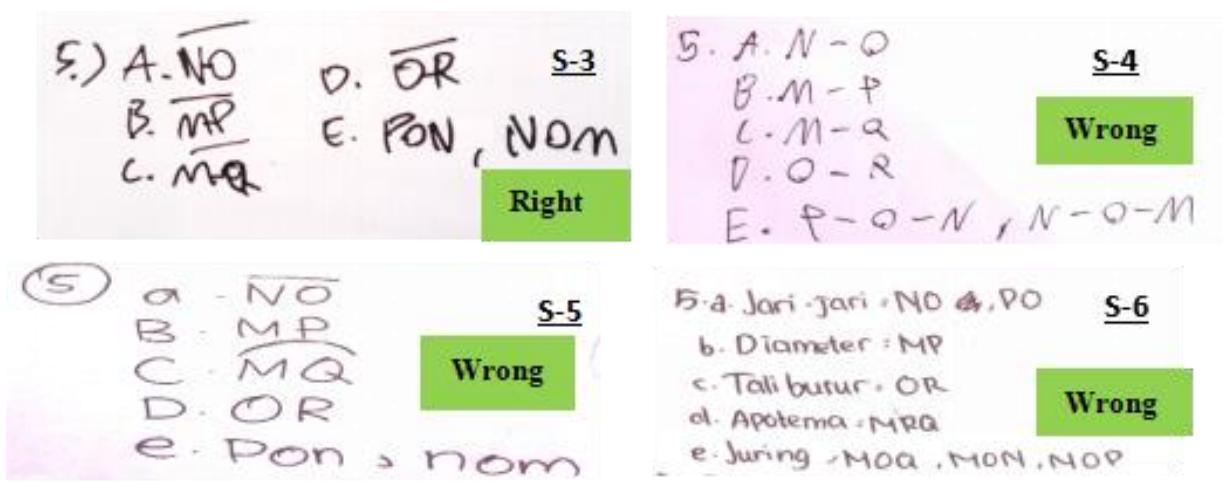

Gambar 3. Hasil jawaban siswa nomor 5

Problem number 5, there are still many students who are wrong in writing notation from circle elements. There is a difference between students 3 (S-3) who write the circle elements notation correctly. Students 4 (S-4), students 5 (S-5), and students 6 (S-6) are not quite right in writing the notation of circle elements but the student understands that part of the circle elements can be seen from the answers which were written. Like students 5 (S-5) who already understand parts of a chord but still write down the notation of a chord, S-5 writes a notation for a bow. While students 6 (S-6) understand well the parts of the circle elements but do not write the notation correctly. This is in line with research (Supandi et al., 2017) that students are understand the material but are wrong in writing symbols and notations. This causes the average of the third indicator in question number 4 and number 5 to be lower than the other indicators.

The first indicator is an indicator stating daily events in language or mathematical symbols have the highest average of 3.46. The first indicator is implemented in problem number 1 that reflects the Quantum Learning model, AGUnk (Apa Gunanya Untuk Ku /What's in it for Me). Students identify the shape of a circle that is in everyday life and give reasons that the object is chosen is a circle. In this way, students can benefit in daily life about circles after learning circle material in class. Students prefer problem solving that involves experiences and ways in their own language. Students prefer to find problems with their own ways and discussions (Martunis, Ikhsan, \& Rizal, 2014). The Quantum Learning Model attracts students' interests because students feel related to their experiences and build knowledge with their own models (Kusno \& Purwanto, 2011).

The written mathematics communication skills of students of class VIII A of Muhammadiyah 2 Malang Junior High School have excellent written mathematical communication skills. This is in line with research from Danaryanti \& Sari (2014). The results of students' mathematical communication skills are in very good criteria by using the Quantum Learning model, because Danaryati's research says that mathematical communication skills can be improved by the Quantum Learning model compared to the direct learning model (Danaryanti \& Sari, 2014). This causes the students' written mathematical communication skills to be in very good criteria with the Quantum Learning model. 


\section{Effectiveness Of The Application Of The Quantum Learning Model to The Mathematics Communication Skills Of Junior High School Students}

The effectiveness of learning is a successful process to achieve learning objectives through a series of activities that have been designed. Effectiveness is the success of a goal under the needs required (Lubis et al., 2017). Learning is said to be effective in this study seen from the observation sheet of the implementation of learning that obtained a score of $\geq 70$ which is in good criteria, and the ability to write mathematical communication of students who obtain an average of all indicators $>2$ that are in good criteria. Therefore, it can be concluded that the application of the Quantum Learning model is effective in the written mathematics communication of students of SMP Muhammadiyah 2 Malang, especially in class VIII A. Things obtained in this study are in line with some of the results of research that has been done regarding the effectiveness of Quantum Learning and the level of communication skills mathematics, but with different research methods as a differentiator in this research.

The results of research conducted by Nurbiah, Halimah, \& Mustamin (2016) state that the effectiveness of learning with the Quantum Learning model in students of SMP Negeri 3 Sungguminasa, Gowa Regency is very effective against mathematical communication skills, especially for students who have difficulty in expressing their ideas. Mathematical communication skills of Sungguminasa Middle School 3 students with the use of the Quantum Learning model are at high criteria (Nurbiah et al., 2016). The results of research that also supports research on the level of mathematical communication ability with the Quantum Learning model are the results of research from Danaryanti \& Sari (2014).

The results of research conducted by Danaryanti \& Sari (2014). states that the use of Quantum Learning models can improve mathematical communication skills and student learning outcomes. Mathematical communication skills of students are in good qualifications on each indicator of mathematical communication presented. Learning outcomes using the Quantum Learning model have an average of an excellent qualification of 86.55 (Danaryanti \& Sari, 2014).

\section{CONCLUSION}

Based on the results of the data analysis, it was concluded that the implementation of learning in class VIII A, SMP Muhammadiyah 2 Malang, in the first to third meeting, was carried out well in accordance with the Learning Implementation Plan or Rencana Pelaksanaan Pembelajaran (RPP), and the written test results of Grade VIII A students who were in the ability of written mathematics communication were very good. So that the application of the Quantum Learning model is effective against the written mathematical communication skills of students of SMP Muhammadiyah 2 Malang. 


\section{REFERENCES}

Agustina, T., \& Sanjaya, F. (2016). Efektivitas Penerapan Model Pembelajaran Berbasis Proyek pada Pokok Bahasan Transformasi Ditinjau dari Hasil Belajar dan Motivasi Belajar Siswa Kelas XI Toi di SMK N 2 Depok Tahun Ajaran 2015 / 2016. Journal Universitas Sanata Dharma.

Danaryanti, A., \& Sari, D. P. (2014). Pengaruh Model Pembelajaran Quantum Learning Terhadap Kemampuan Komunikasi Matematis dan Hasil Belajar Siswa Kelas XI SMA. EDU-MAT Jurnal Pendidikan Matematika, 2(1), 29-37.

Darkasyi, M., Johar, R., \& Ahmad, A. (2014). Peningkatan Kemampuan Komunikasi Matematis dan Motivasi Siswa dengan Pembelajaran Pendekatan Quantum Learning pada Siswa SMP Negeri 5 Lhokseumawe. Jurnal Didaktik Matematika, 1(1), 21-34.

DePorter, B., Reardon, M., \& Nourie, S. S.-. (2010). Quantum Teaching. Bandung: PT.Mizan Pustaka.

Elli, K., \& Manopo. (2016). Meningkatkan Kemampuan Komunikasi Matematis Siswa Menggunakan Model Pembelajaran Quantum Pada Materi Garis Dan Sudut Di SMPN 13 Banjarmasin. EDU-MAT Jurnal Pendidikan Matematika, 4(2), 118-125.

Haryoko, S. (2009). Efektivitas Pemanfaatan Media Audio-Visual Sebagai Alternatif Optimalisasi Model Pembelajaran. Jurnal Edukasi Elektro, 5(1), 1-10.

Kusno, \& Purwanto, J. (2011). Effectiveness of Quantum Learning for Teaching Linear Program at the Muhammadiyah Senior High School of Purwokerto in Central Java, Indonesia. EDUCARE: International Journal for Educational Studies, 4(1), 83-92.

Lubis, R. S., Sari, R. F., \& Cipta, H. (2017). Efektivitas Pembelajaran Model GrashaRiechmann Terhadap Prestasi Belajar Matematika Siswa. Makalah Disajikan Pada Seminar Nasional Matematika Dan Aplikasi 2017, UIN Sumatera Utara.

Lusiana, L., Hartono, Y., \& Saleh, T. (2013). Penerapan Model Pembelajaran Generatif (Mpg) Untuk Pelajaran Matematika Di Kelas X Sma Negeri 8 Palembang. Jurnal Pendidikan Matematika, 3(2).

Martunis, Ikhsan, M., \& Rizal, S. (2014). Meningkatkan Kemampuan Pemahaman dan Penalaran Matematis Siswa Sekolah Menengah Atas Melalui Pendekatan ProbingPrompting. Jurnal Didaktik Matematika, 1(2), 75-84.

Marwoto Saiman, \& Slameto. (2008). Model Pembelajaran Quantum Teaching untuk Meningkatkan Hasil Belajar IPS Kelas V SDS Kalam Kudus Kecamatan Tebing Tinggi, Kabupaten Bengkalis. Jurnal Ilmu-Ilmu Sejarah, Budaya Dan Sosial, 89-117.

Ningrum, L. S. (2013). Analisis Kemampuan Siswa Menyelesaikan Soal Matematika dalam Bentuk Cerita Pokok Bahasan Barisan dan Deret Pada Siswa Kelas XII SMA Al-Islam 3 Surakarta. Skripsi S1 Pendidikan. Universitas Muhammadiyah Surakarta.

Nurbiah, Halimah, A., \& Mustamin, S. H. (2016). Efektivitas Penerapan Model Pembelajaran Quantum Teaching Terhadap Kemampuan Komunikasi Matematis Siswa. Alauddin Journal of Mathematics Education, 1(2), 33-36.

Ramadhan, I., \& Minarti, E. D. (2018). Kajian Kemampuan Komunikasi Matematik Siswa SMP Dalam Menyelesaikan Soal Lingkaran Pembelajaran Matematika Yang Memiliki IX SMP Pada Materi lingkaran. Journal of Mathematics Education IKIP Veteran Semarang, 2(2), 151-161.

Rohmawati, A. (2015). Efektivitas Pembelajaran. Jurnal Pendidikan Usia Dini, 9(1), 1532. 
Sari, I. P. (2017). Kemampuan Komunikasi Matematika Berdasarkan Perbedaan Gaya Belajar Siswa Kelas X SMA Negeri 6 Wajo pada Materi Statistika. Jurnal Nalar Pendidikan, 5(2), 86-92.

Sudarman, S. W., \& Vahlia, I. (2016). Efektifitas Penggunaan Metode Pembelajaran Quantum Learning terhadap Kemampuan Pemahaman Konsep Matematis Mahasiswa. Al-Jabar: Jurnal Pendidikan Matematika, 7(2), 275-282.

Supandi, Rosvitasari, D. N., \& Kusumaningsih, W. (2017). Peningkatan Kemampuan Komunikasi Matematis Melalui Strategi Think-Talk-Write. Jurnal Kependidikan, 1(2), 227-239.

Tasaik, H. L., \& Tausikal, P. (2018). Peran Guru Dalam Meningkatkan Kemandirian Belajar Peserta Didik Kelas V SD INPRES Samberpasi. Metodik Didaktik, 14(1), 4555.

Wigati, F. A. (2016). The Effect Of The Implementation Of Quantum Teaching Strategy In Teaching Writing a Descriptive Text. Jurnal Pendidikan UNSIKA, 4(1), 42-50.

Yaniawati, R. P. (2019). Core Model on Improving Mathematical Communication and Connection, Analysis of Students ' Mathematical Disposition. International Journal of Instruction, 12(4), 639-654. 